\title{
The International Payments System and Farm Exports
}

\author{
A Speech by DARRYL R. FRANCIS, President, \\ Federal Reserve Bank of St. Louis, to the \\ St. Louis Agribusiness and World Trade Clubs, October 22, 1970
}

T IS GOOD to have this opportunity to discuss with you some vital issaes of international trade. Each of us has an interest in this subject - some as producers of goods which compete with imports, others as producers who export part of their output, and all as consumers who gain from the effeiencies of international specialization of labor and resource use.

First, I shall briefly review some historical developments in our intemational payments system. Then, I shall discuss certain policy actions that have been taken to increase foreign trade and, finally, basic factors which tend to limit foreign trade expansion.

\section{Earlier Payments System - Self-Adjusting}

In the half century prior to World War 1 , the Western World had a self-equilibrating system of settling intemational accounts. Most commercial nations were on the gold standard with the domestic stock of money tied to the stock of gold. A balanceof-payments deficit led to a gold outflow which, in tum, led to a reduction in the nation's money stock. A decline in the stock of money reduced domestic demand for goods and services, thereby discouraging imports and encouraging exports. This process continued until the balance-of-payments deficit was eliminated.

With the monetary disruptions during the war, most nations left the gold standard. In the 1920's, at tempts were made to restore the system, but the relationships established between carrencies and gold were often set at the pre-war rates, and some important currencies were overvalued. In those countries with overvalued currencies, imports were stimulated and exports declined, thereby depressing their econom mies. Attempts were made to make the necessary adjustments, but the depression of the 1930 's dealt a death blow to the gold standard before new equilibrium rates could be restored.
Losing gold in a period of growing unemployment like the 1930 's meant further contraction of national money stocks and further deflation. Most nations consequently broke the link between gold and domestic money, being unwilling to let international gold movements influence the domestic money stock and income. Following the breakdown of the gold standard, most nations moved to a gold exchange system in which national currency values were arbitrarily pegged to the dollar and the dollar pegged to gold.

\section{Current System Not Self-Adiusting}

The gold exchange system automatically permitted free currency convertability among participating countries. Under the present system, funds flowing out of a country reduce its intemational reserves just as under the gold standard in former years. Now, however, these flows can be offset by central bank actions, and they have no automatic impact on do. mestic money, prices, and income. Actions can be taken by central bankers to reduce the stock of money and the demand for goods and services and put a brake on domestic prices when international reserve outflows occur, but such actions now reflect conscious policy rather than the automatic operation of the system. Because of these destablizing effects on domestic income and prices, stch actions are taken with extreme caution. We are thus at times tom between actions for implementing balance-of-payments objectives and actions for optimum domestic conditions.

A few nations have altered their exchange rates when large excesses or shortages developed in their foreign exchange accounts. The United Kingdom reduced the value of the pound as a result of a large and continuous deficit, while Germany increased the vatue of its currency following a large and continuous surplus. This method of changing the terms of trade has not proven a practical solution to the United 
States, as the dollar is a key intemational reserve currency widely held for official balances. Any reduction in its value in terms of gold would result in an immediate loss to all foreign dollar holders.

Other methods used to maintain a balance-of-payments surplus include tariffs, import quotas, capital export controls, and foreign travel restrictions. Each of these methods, however, tends to reduce the volume of international trade. In most instances, they are abitrary and subject to extreme abuse by the enforcing agencies.

The special drawing rights (SDRs) activated by the Intemational Monetary Fund (IMF) early this year extended the period over which an imbalance of intemational payments can occur. These rights essentially increase the quantity of intemational money by a regulated amount of SDRs each year, with the MF acting as a clearing agent. Although serving to ease the problem of short-run payment imbalances, SDRs do nothing to alter the terms of trade or reverse basic imbalances. Terms of trade between two nations are altered in the market by changes in national price levels and exchange rates. The SDRs permit more time for a nation to take actions to alter the terms of trade and are beneficial in this respect. Nevertheless, if basic steps are not laken to equilibrate the terms of trade, an imbalance of international payments on the basis of fixed exchange rates cannot persist indefinitely without total loss of foreign exchange holdings.

\section{Recent U. S. Experience}

With this background, let us briefly review the U. S. situation with reference to the balance of payments and holdings of foreign exchange. Following World War II, this country had a gold balance of $\$ 24$ billion, or about two-thirds of the free world's stock of gold. We were likewise endowed with a large portion of the free world's productive capacity. Justifiably, domestic policies were instituted to provide other nations of the free world with a better balance in foreign exchange. We generally maintained expansive monetary and fiscal policies and engaged in massive foreign aid programs, which tended to reduce $U$. S. gold stocks. By early 1968 our gold stock had declined to $\$ 10.7$ billion, only slightly more than one-fourth of the world's total. Our gold holdings have since increased slightly, but the basic factors underlying our balanceof payments position have not improved.

Our needs for foreign exchange, like an individ ual's needs for castl balances, depend upon the vol- ume of transactions to be settled and the synchronization of receipts and payments. Since international trade by the United States accounts for only about one-sixth of the world's total, we apparently do not need two-thirds of the free world's stock of gold pos. sessed twenty years ago. Yet, in view of the volume of our international transactions and the foreign claims held on the United States, we do need a sizable stock of gold. Most importantly, however, we require means for altering the balance of payments to avoid further loss of liquidity. To alleviate this problem, I would suggest greater flexibility in setting exchange rates between the dollar and other currencies. A system of "crawling" exchange rates, whereby the rates are permitted to change a small amount each week or month toward new market levels when imbalances occur, would be a major improvement over the current system. By altering rates to meet payment inbalances, the monetary authorities can concentrate on the appropriate actions for domestic stabilization.

\section{Protection - The Major Trade Restraint}

Although the intemational payments system has imperfections, it probably is not the major factor tending to retard trade growth. Policies designed to protect domestic producers from foreign competition have probably been a more important restraint to foreign trade. All commencial nations pursue protectionist policies which reduce the quantity of goods and services available to consumers, and we are equally guilty of this practice. When the nation was young, it levied tariffs for income in preference to domestic taxes. Later, tariffs were raised to protect our so-called infant industries from foreign competition. The protectionist argument still prevails in one form or another. Between 1865 and 1935 our average rate on dutiable imports never fell below 39 per cent, except for the period during and immediately following the First World War when other nations had a very small output of civilian goods for export." The Underwood Law in 1914 imposed an average rate of 29 per cent on dutiable imports, which was raised to 39 per cent in 1923 under the Fordney MoUmber Law and further increased to 53 per cent in 1930 under the Hawley-Smoot Law.

Since the Reciprocal Trade Agreements Act of 1934, the nation has pursued an announced policy of "freeing" international trade. Numerous tariff reductions have been negotiated. Nevertheless, duties have of-

\footnotetext{
1Don D. Humphrey, American Imports (New York: The Twentieth Century Fund, 1955), p. 74.
} 
ten remained so high and other restrictions so effective that foreign trade has not been greatly freed.

\section{Protection Through Nontariff Barriers}

While tariffs have traditionally been the chief means of protecting domestic producers from foreign competition, other protective devices have increasingly been used in recent years. Chief among them are import quotas; domestic subsidies; bilateral trade agreements; import licensing; domestic monopolies operating under governmental authority; and "voluntary" controls, such as the case of cotton textiles. In some instances, the restrictions have involved special legislation. In others, informal agreements have been sufficient to limit trade to arbitrarily determined levels. With the aid of one or more of these measures, nations can maintain tariff duties at relatively moderate levels and still protect producers from foreign competition. This change in method of protection provides an opportunity for great obscurity in discussing trade policies and results of tariff reduction agreements. A reduction in tariff rates may have little meaning, since real barriers to trade often remain unchanged.

International trade barriers are as unreasonable under competitive production and marketing conditions as are trade bartiers between states, cities, or counties. To the extent that they reduce the volume of goods and services traded, they reduce welfare.

Our country has not been innocent with respect to the use of these protective devices. Even in agricul ture, which has such a large stake in free trade, we have established highly protectionist policies. We have sugar import quotas which, based on the New York wholesale price, cost U. S. consumers an additional 4 cents for each one pound of sugar purchased. ${ }^{2}$ We have subscribed to international trade agreements which set minimum prices on coffee and wheat, thereby limiting trade in these commodities. We have meat import quotas which provide limits on imports of beef. Our cotton export stibsidy, designed to offset the tradewretarding features of our domestic price support program, is sufficient to permit exports of cotton to Japan and imports of goods made from the cotton to the U.S. for sale in competition with our own mills. In order to avoid excessive disruptions from such competition, however, we have a tacit agreement with the Japanese to limit cotton goods exports to the United States. Such tacit arrangements International Monetary Fund, Intenational Financial Sta-
tistics, Sept. 1970, p. 29 . are apparently preferred over formalized legal actions, but, if they are equally effective in reducing trade, they are likewise equally effective in reducing welfare.

\section{Domestic Subsidies Restrictive}

Also important in limiting foreign trade are production controls and subsidies. For a number of years, the British have subsidized their farm production, maintaining excessive labor in agriculture which, in effect, limits their imports and our exports of farm products to them. These workers could produce more real income in nonfarm pursuits, and, under free trade conditions, the British would export more nonfarm products and import more farm products, thereby enhancing their total production and welfare.

Our own domestic farm programs inhibit world trade. Despite an announced policy of free trade since 1934 and lower tarif rates, our domestic farm policies have probably offset the advantages gained from the reduced tariff levies. Farm production control and price support programs were initiated in the mid-1930's which contributed to higher farm production cost and higher prices for farm products both here and abroad. Our farm products became less competitive in the world market. Worse, from a longrange view, our policy of arbitrary farm product pricing at higher than free market levels led to a loss of confidence in the United States as a long-run source of farm products. This move from competitive to arbitrary pricing indicated to our customers abroad that hereafter prices of U.S. farm commodities would be in excess of free market prices. Higher export prices in tum indicated higher food and fiber costs to importing nations. Their costs of imported food thus hinge on the decisions of our price-making authorities, who are likely to be more influenced by political pressures at home than by living costs elsewhere.

\section{International Trade Impeded}

Our tariff reduction policies have not led to more trade relative to total ontput. In the $1920-34$ period, prior to the Reciprocal Trade Agreements Act, U.S. commodity exports averaged 5.1 per cent and imports 4.1 per cent of gross national product (Table 1). In contrast, since the announced liberal trade policies in the mid-1930's, total exports have averaged only 4.1 per cent and imports only 2.9 per cent of GNP. The proportion of foreign trade in farm products declined even more shapply than the total. Commercial farm exports declined from 17.4 per cent of farm out put in the 1920-34 period to 8.6 per cent since 1934 , 


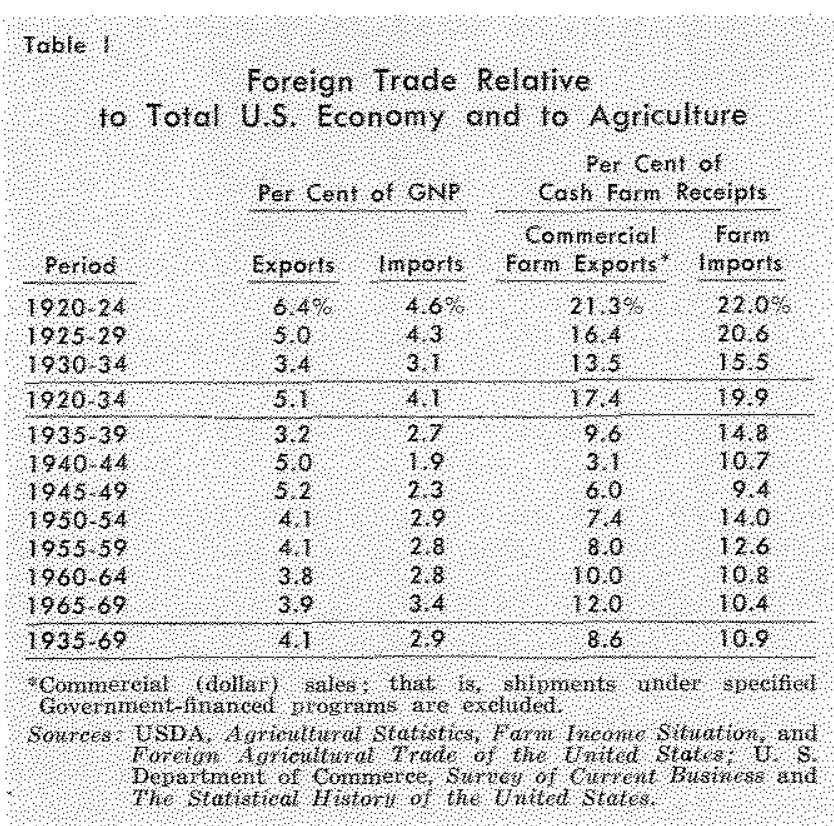

and imports declined from 19.9 to 10.9 per cent. In the five-year period 1965-69, commercial farm exports totaled 12 per cent of cash farm receipts, somewhat above the 1935-69 average but well below the per cent exported prior to the somcalled change to more liberal trade policies. Furthemore, export subsidies such as government credits and guarantes, govemment commodity sales at less than market prices, and export payments in cash were responsible for a large portion of recent exports. We view such practices as "dumping" when other countries export products to us under similar conditions.

Thus, despite our announced freer trade policies, our new barriers to intenational trade have offset our tradeufreeing actions. The trade barriers are usually imposed in such a way as to inhibit trade growth rather than have a strong immediate impact, and thus become successively more restrictive over time.

It is my conclusion that the predoninent political forces in most nations today do not really want large increases in foreign trade. Large gains in trade upset markets and cause changes in resource use. Some hardships occur in the short rum in the relatively less efficient industries. Cains ocour immediately, however, in the relatively inore efficient industries and among all consumer groups. In the longer run, all groups gain from the greater efficiency of intemational specialization. But, neither this nation nor other nations have to date indicated a willingness to adopt policies that will assure these major gains at the expense of minor adjustments among some producer groups.

\section{Restrictive Arguments Fallacious}

Despite the fact that international welfare could be greatly enhanced through freer trade practices, the arguments of trade restrictive proponents have been predominent in determining public policies among leading commercial nations during the last half century. Reasons given for import restrictions are as follows:

1. Large imports of farm products lower domestic prices and farm incomes;

2. It is unfair to domestic labor to compete with producers under "sweatshop" conditions abroad;

3. Imports are not a reliable source of vital products, such as food and chitical defense items; and

4. Excessive imports damage vital defense industries which are necessary for survival. ${ }^{3}$

Implicit in each of these arguments are the beliefs that import restrictions aid certain producer groups, or that some industries are so vital to national survival that we cannot afford to take the risk of relying on imports exclusively for such products.

The argument that import restrictions aid some producer groups is true only in the short run. Over the longer run, labor and other resources adjust to new supply and demand conditions, and real gains accrue to all groups. Furthermore, even in the short run such restrictions are at the expense of the rest of the nation.

Let us take agriculture as an example and consider the impact of greater exports of American farm products to Western Europe. Such exports will first cause a reduction in prices to European farmers and a reduction in food costs to European consumers. Their farm incomes will decline, providing incentive for farm workers to seck higher paying jobs in the nonfarm sector. The larger nonfarm labor force, which is relatively more efficient, will achieve greater output of nonfarm goods and services, and exports of these products to the United States will increase. Greater efficiencies will occur in both their farm and nonfarm sectors, and a larger volume of all products will be available at lower prices, enhancing real incomes and welfare. On the American scene, the larger volume of farm exports will tend to increase domestic farm prices and incomes. This will attract new resources into agriculture from other sectors or, more likely, reduce the outflow of resources from agriculture. The larger imports of nonfarm products by the United States will reduce demand for resources in our non

"Himphrey, Chapter 7. 
farm sector, but, similar to the European case, the increased efficiencies will provide more goods and services to our people.

The argument that imports from low-cost factories abroad are unfair to labor is similar to the farm import argument. Import restrictions aid workers in im" port-competing industries in the short run, but injure workers in export industries. But, once workers and other resources have adjusted to the new market forces, greater output is achieved and the benefits of greater production efficiency accrue to all.

Almost all major countries subscribe to the "vitalindustries" argument for protection. Certain industries are assumed to be vital for national survival. England, for example, has in the past attempted to maintain domestic food production at about 50 per cent of do" mestic usage. These policies originated from a lack of confidence in supplies from abroad at critical periods, such as during wartime blockades. Many other nations, including our own, prefer to maintain sufficient resources in vital lines of production to provide a minimum level of output in case of loss of supplies from abroad. Oil and sugar quotas here are an example of such protection. Nations are willing to maintain production of these vital products, despite the fact that such inefficient use of resources is a waste of effort. Protection for these industries against competition from abroad maintains stability of employment for a few at the expense of many. Nations are willing to tax more for defense items and pay higher prices for the civilian output of such industries in order to maintain these industries, despite the fact that methods of modem warfare have made such excuses obsolete. Nations now have the power to destroy one another long before supplies of such critical products are depleted. The solution lies in increased confidence that world trade channels will remain open and supply sources unimpaired.

From the standpoint of U.S. agriculture, we look abroad at the rapid growth of Western European nations and see great opportunities for farm commodity exports, provided these nations will only open their trade doors and invite us in. It is my conclusion that we have not eamed the invitation. Despite our numerous pronouncements, our policies have not contributed to two-way trade arrangements. We have done little to merit the dependence by Westen European nations upon us for an indefinite source of vital products at competitive prices. We have followed neither tariff, quota, or other import regulatory poli- cies nor domestic pricing policies that are conducive to free trade.

Although the arguments are overwhelming in favor of more trade between nations, I am quite pessimistic as to its future course. Forces tending to reduce wefare through trade barriers are better financed and more powerful than the forces active in promoting welfare through freeing trade channels. As an indication of the power of protective groups, about 590 import quota proposals were introduced in the recent session of Congress prior to the end of August." One bill, approved by the House Ways and Means Committee, was described by the New York Times as the "most protectionist and reactionary trade legislation in forty years." Signs admonishing us to purchase American goods and protect American jobs can be observed daily. Only the textbooks, however, are available to point out the gains from free trade, and few professors are reporting the story to the general public.

\section{Summary}

In summary, our international payments system has imperfections. It is not self-equilibrating as it was under the gold standard prior to World War I. It has not, however, been the major factor tending to retard foreign trade growth. This growth has been retarded because neither the political forces in this nation nor other nations are willing to forego the short-run in terests of a few producer groups for the general welfare of the nation.

There are few who deny the gains from greater exports, but powerful groups fear a rise in imports. Both exports and imports enhance total welfare. The removal of trade restrictions would be especially beneficial to American agriculture. We have a major relative advantage in the production of farm commodites. Under free world trade policies and free domestic producing conditions, world-wide food prices could be lowered and world diets improved. The Reciprocal Trade Agreements Act, the recent Kennedy Round, and numerous other acts were designed to achieve these objectives. Proposed modem liberal policies, however, are often followed by restrictive actions more typical of the mercantilist ages. In practice we still follow the obsolete theories of several centuries ago.

Most of the arguments used against free trade practice are not applicable to modern world condi-

International Commerce, Sept. 7, 1970, p. 10.

5New York Times, Sept. 21, 1970 . 
tions. The implied disruptions in local industries are generally overstated and are often excuses for maintaining resources in inefficient lines of production. Current unemployment insurance and labor retraining social programs minimize hardships to the labor force resulting from the change. Little capital loss would likely occur, as our heavily capitalized industries are better able to compete in the world market due to technological change. The vital-industries argument is no longer applicable, since, in case of all-out war under modern conditions, no industry is secure regardless of where it is located.

The United States should take the lead in dropping all trade barriers. Tariffs are not the only item to consider. We should move immediately to build world confidence in us as a supplier and market. Real accomplishments will require more than the rhetoric of recent decades followed by high level conferences, which tend to free trade where no potential trade exists. We must be willing to remove barriers, permit major increases in imports, and oppose the power of producer groups who have made their short-run in terest paramount to the welfare of the nation. We must be willing to dismantle our inefficient production controls in agriculture and assure foreign consumers that our farm products will be available at competitive prices. A move toward free trade is a move toward less Government control of prices and production and greater reliance on market forces for resource adjustment.

These moves are counter to the great surge to alleviate :ll individual hardships through general legislation which temporarily aids the few but reduces national welfare. Their adoption can reverse the trend to isolationism in the current century and greatly enhance the welfare of both our own citizens and those of the rest of the world.

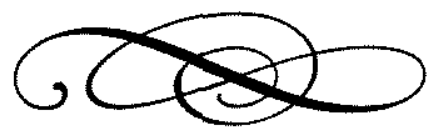

